\title{
COVID-19 and the Kidneys: An Update
}

\author{
Claudia Benedetti ${ }^{1}$, Meryl Waldman ${ }^{2}$, Gianluigi Zaza ${ }^{3}$, Leonardo V. Riella ${ }^{4}$ and \\ Paolo Cravedi ${ }^{\text {* }}$
}

${ }^{1}$ Department of Medicine, Icahn School of Medicine at Mount Sinai, New York, NY, United States, ${ }^{2}$ Kidney Disease Branch, National Institute of Diabetes and Digestive and Kidney Diseases, National Institutes of Health, Bethesda, MD, United States, ${ }^{3}$ Renal Unit, Department of Medicine, University Hospital of Verona, Verona, Italy, ${ }^{4}$ Renal Division, Harvard Medical School, Massachusetts General Hospital, Boston, MA, United States

The new coronavirus disease 2019 (COVID-19) has become a world health emergency. The disease predominantly effects individuals between 30 and 79 years of age with $81 \%$ of cases being classified as mild. Despite the majority of the general population displaying symptoms similar to the common cold, COVID-19 has also induced alveolar damage resulting in progressive respiratory failure with fatalities noted in $6.4 \%$ of cases. Direct viral injury, uncontrolled inflammation, activation of coagulation, and complement cascades are thought to participate in disease pathogenesis. Patients with COVID-19 have displayed kidney damage through acute kidney injury, mild proteinuria, hematuria, or slight elevation in creatinine possibly as consequence of kidney tropism of the virus and multiorgan failure. The impact of COVID-19 on patients with pre-existing kidney

OPEN ACCESS

Edited by:

Ying-Yong Zhao,

Northwest University, China

Reviewed by:

Umberto Maggiore,

Decision Research, United States

Bassam G. Abu Jawdeh,

University of Cincinnati, United States

*Correspondence:

Paolo Craved paolo.cravedi@mssm.edu

Specialty section:

This article was submitted to Nephrology,

a section of the journal

Frontiers in Medicine

Received: 17 April 2020

Accepted: 30 June 2020

Published: 21 July 2020

Citation:

Benedetti C, Waldman M, Zaza G, Riella LV and Cravedi $P$ (2020) COVID-19 and the Kidneys: An Update. Front. Med. 7:423. doi: 10.3389/fmed.2020.00423 impairment, including those with chronic kidney disease, kidney transplant recipients, and individuals on hemodialysis (HD) has not yet been clearly established. No specific treatments for COVID-19 have been found yet. Research has revealed several agents that may have potential efficacy against COVID-19, and many of these molecules have demonstrated preliminary efficacy against COVID-19 and are currently being tested in clinical trials.

\section{Keywords: acute kidney injury, AKI, COVID-19, dialysis, transplant}

\section{INTRODUCTION}

Severe acute respiratory syndrome coronavirus 2 (SARS-CoV-2), first described in humans in December 2019 in Wuhan, China (1), is the third coronavirus to have emerged in the last 20 years. Previous outbreaks of the severe acute respiratory syndrome coronavirus (SARS-CoV) in 2002 and the Middle East respiratory syndrome coronavirus (MERS-CoV) in 2012 have been toppled in case incidence by the global impact of SARS-CoV-2 (2).

As of May 25, 2020, 5,370,375 infected cases have been confirmed with 344,454 deaths across 216 countries, areas or territories (3). SARS-CoV-2 was declared a pandemic on March 11, 2020 by the World Health (1).

Presentation of symptoms for COVID-19 infection can be seen 2-14 days after exposure. These symptoms include fever, cough, and difficult breathing $(4,5)$. A severe complication of this disease is progressive respiratory failure, and death may occur in $6.4 \%$ of the cases $(3,6,7)$. The potential impact of SARS-CoV-2 on the kidneys is still undetermined, but emerging evidence indicates that kidney complications are frequent, and COVID-19 disease may have unique features in individuals on chronic dialysis and kidney transplant recipients (8). 


\section{SARS-CoV-2 AND COVID-19 PATHOPHYSIOLOGY}

The coronavirus derives its names from its physical form: a spherical virion with spike (S) proteins (9). There are four subfamilies of coronaviruses, namely $\alpha_{-}^{-}, \beta-, \chi_{-}^{-}$, and $\delta$-coronaviruses; SARS-CoV-2 is a $\beta$-coronavirus like its predecessor, SARS-CoV (9). The relationship between the current strain and previously identified strains through highthroughput sequencing has allowed epidemiologists to trace the evolution of the virus. A closely related strain found in bats, RaTG13-2013, shares $96 \%$ of the genome (4). This has led scientists to believe that the virus jumped between host species from the bat, or an intermediate animal, before spreading amongst the human population (4).

The spike protein is key to its high-virality as the RNA virus enters cells through binding between the $S$ protein and its host receptor. The virus efficiently binds to the angiotensin converting enzyme 2 (ACE2) receptor (10) which is highly expressed in many organs including the bronchus and lung parenchyma, heart, kidney, and gastrointestinal tract (Figure 1A) $(6,12,13)$. Zhao et al. demonstrated that ACE2 is highly expressed in the alveolar epithelial type II cells (AECII), suggesting that these cells could be the reservoir for the virus. Other studies have showed that the AECII cells have several genes related to the viral process, replication, life cycle and assembly, therefore facilitating the viral replication in the lung (10).

After binding to ACE2, the cellular transmembrane protease, serine 2 (TMPRSS2) mediates the $\mathrm{S}$ protein priming allowing the virus to enter the host cells through clathrin-dependent endocytosis (Figure 1B) (13). The endosomal entry way for the virus requires a low inner $\mathrm{pH}$, and once inside, the virus exploits the cellular transcriptional machinery to replicate itself and spread throughout the host (8). By hijacking the endogenous transcriptional machinery, the virus alters the behavior of the host cells and tissue making them unable to fulfill their normal function.
There are two phases to the immune response induced by SARS-CoV-2 (14, 15): (1) an initial specific adaptive immune response and (2) uncontrolled inflammation. The adaptive response is required during the early stages of incubation to prevent the progression of disease and eliminate the virus. When the protective immune response is ineffective, the virus propagates, inducing destruction of the affected tissues leading to severe disease progression (15). An uncontrolled inflammatory response is also implicated in COVID-19, as a mechanism responsible for acute respiratory distress syndrome (ARDS). The release of a cytokine storm may promote apoptosis or necrosis of $\mathrm{T}$ cells, and consequently lead to their reduction (16). This violent assault can be seen in patients with severe disease who's plasma levels of IL-6, TNF $\alpha$, and IL-10 are higher, and circulating CD4 and CD8 T cells are lower than patients with mild COVID-19 or healthy controls (17). This trend is even stronger in elderly patients. Intriguingly, most severe COVID-19 cases also have increased percentages of T cells with exhaustion phenotype. Therefore, it is tempting to speculate that uncontrolled inflammation, while promoting ARDS, impairs viral clearance by inducing $\mathrm{T}$ cell exhaustion (18).

\section{Complement Activation in COVID-19}

The complement system is an important component of innate immunity that is essential to respond rapidly to infection. During inflammation, both acute and chronic, activation of the complement system promotes the elimination of pathogens. Dysregulation of the complement system may lead to acute lung disease after a highly pathogenic viruses infections (19).

Complement activation through the lectin pathway has already been described in SARS-CoV-2 infected patients. Gao et al. (20) showed that blocking this pathway ameliorates lung injury induced by SARS-CoV and MERS-CoV in mice. Autoptic lung samples and skin biopsies from patients with severe COVID-19 showed a deposition of mannose binding lectin (MBL)-associated serine protease (MASP)2, C4d, and C5b-9 (MAC component), suggesting an activation of the
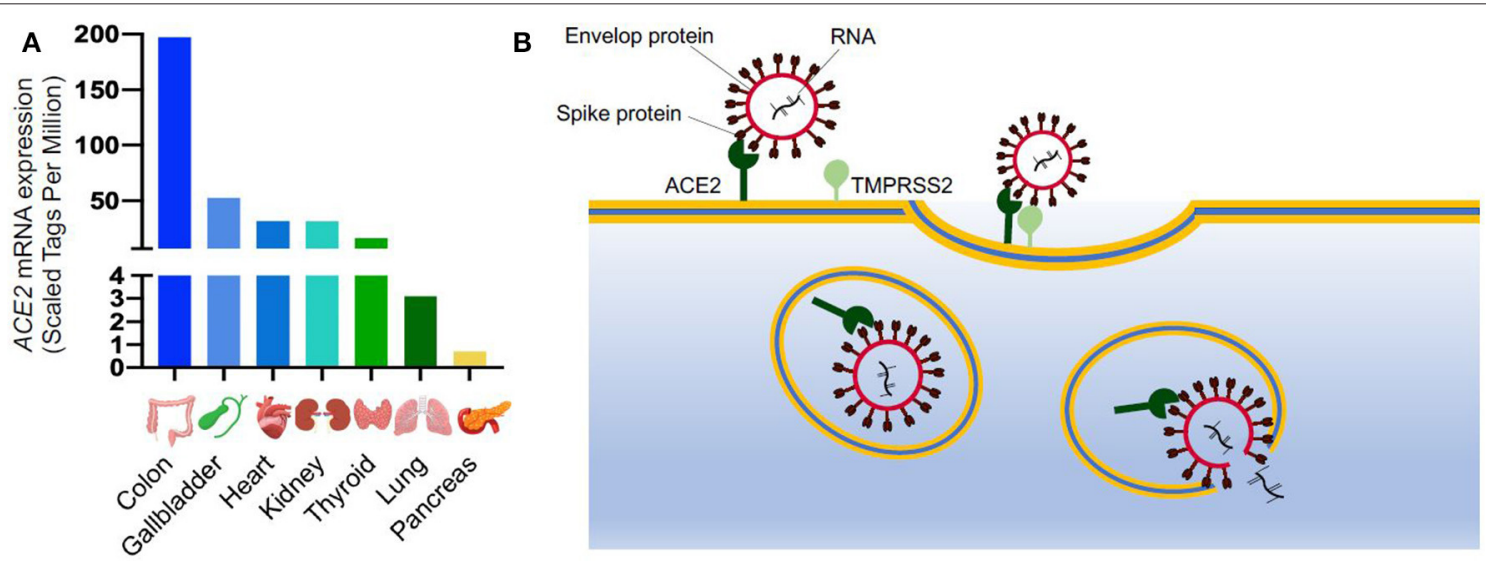

FIGURE 1 | SARS-CoV-2 entry into the cells. (A) ACE2 mRNA expression in different organs from FANTOM5 dataset (11); (B) Schematic of SARS-CoV-2 entry into the cells. ACE2 is expressed on cell surface and it is recognized by the spike protein of SARS-CoV-2. After binding to ACE2, the viral spike glycoprotein is primed by a host serine protease (TMPRSS2), which allows internalization by endocytosis. Once inside the cells, SARS-CoV-2 replicates utilizing the cellular transcriptional machinery. ACE2, Angiotensin-Converting Enzyme 2; SARS-CoV-2, Severe Acute Respiratory Syndrome Coronavirus 2; TMPRSS2, Transmembrane Serine Protease 2. 
complement system through the alternative and the lectin pathways (21). Preliminary data from patients treated with an anti-complement C5a blocking antibody also suggested a potential benefit of complement targeting therapies in COVID19 patients with severe lung injuries (20). Due to the implicated role of complement in the pathogenesis of acute lung injury and ARDS, ongoing clinical trials are testing the hypothesis that blocking the complement cascade ameliorates disease severity in COVID-19 patients.

\section{Hypercoagulability and Thrombosis in COVID-19}

In general, altered hemostasis due to viral infections often leads to vascular complications like thrombosis and or hemorrhage. Vascular and endothelial changes by the virus as well as inherited host factors help define the clinical presentation. Some viral contributions to the ischemic and thrombotic environment include procoagulant factors, hemodynamic changes, and pro-inflammatory cytokines. The pro-inflammatory response also directly induces plaque rupture (22-25). This can be seen with many respiratory viruses like $\mathrm{H} 1 \mathrm{~N} 1$ influenza (26) and is of increasing concern for patients with severe COVID-19. The majority of severe COVID-19 patients show signs of increased coagulation activity, resulting in consumption of coagulation factors and disseminated microvascular thrombosis. Hypoxia associated with COVID-19 pneumonia increases blood viscosity both directly and through hypoxia-inducible transcription factor-dependent signaling pathway thereby promoting thrombosis (27). Laboratory results indicate a prolongation of the prothrombin time and international normalized ratio (PT/INR) and partial thromboplastin time (PTT), elevation of D-dimer, decreased fibrinogen levels, thrombocytopenia, and schistocytes in peripheral blood smears. In one study of 449 COVID-19 patients, $71 \%$ of non-survivors had diffuse intravascular coagulation (DIC) compared to $0.4 \%$ of survivors (27). Zhou et al. (25) showed that death is associated with D-dimer $<1 \mu \mathrm{g} / \mathrm{mL}$ in a retrospective study of 191 COVID-19 patients. Elevated D-dimer at admission and markedly increasing D-dimer levels during the disease were associated with high mortality (27).

Recently, anti-phospholipid antibodies and infarcts in multiple vascular territories have been reported in three COVID19 patients with thrombocytopenia. It is known that these antibodies can increase during several infections, and critical illness and may lead to thrombotic events (28).

Based on this data, a prophylactic dose of low molecular weight heparin has been advised to hospitalized COVID-19 patients, despite abnormal coagulation tests, and the thrombotic risk associated with prolonged bed resting (27).

\section{COVID-19 DISEASE NATURAL HISTORY}

SARS-CoV-2 rapidly spread throughout the world since its first case and very few countries to date have not reported at least one case of the disease within their borders. One infected patient may transmit the virus to 2 or 3 other individuals, and asymptomatic patients may also spread the virus $(29,30)$. The proportion of this asymptomatic population remains unknown (4). Transmission of the SARS-CoV-2 occurs through direct human-to-human contact and through respiratory droplets in the air or on surfaces (31). The virus remains viable in aerosols for over $3 \mathrm{~h}$ without a significant reduction in its infectious titer and for up to $72 \mathrm{~h}$ on plastic and stainless steel $(32,33)$.

Approximately $80 \%$ of patients infected by SARS-CoV-2 present with mild disease and can recover spontaneously (34). The other $20 \%$ of patients present with severe disease and $6 \%$ become critically ill (35). In these symptomatic patients, the main signs manifest as an upper respiratory tract infection, cough, fever, and asthenia. Patients with severe disease will present with pneumonia suspected by the presence of decreased oxygen saturation, lymphopenia and increased inflammatory markers (CRP, D-dimer, ferritin) $(4,36)$. Chest CT scans usually show bilateral involvement of the lungs, with consolidation in subsegmental areas (16). Viral pneumonia can evolve into severe acute hypoxic respiratory failure mediated by increased pulmonary capillary permeability and damage of the alveolar epithelial cell (35).

The main risk factor for mortality due to COVID-19 is advanced age. In patients with comorbidities, such as chronic kidney disease, hypertension, chronic obstructive pulmonary disease, diabetes, tumor, and obesity, advanced age was the strongest predictor of a poor outcome with infection $(33,35,37)$. Male sex has also been proposed as a risk factor in some studies (1), but this is not an universal finding (38).

\section{KIDNEY INVOLVEMENT DURING COVID-19}

Li et al. (39) analyzed kidney function in 193 COVID-19 patients and found that $31 \%$ of patients had an elevated level of blood urea nitrogen (BUN) and $22 \%$ had increased serum creatinine. These authors also found also that in 147 patients, $60 \%$ exhibited proteinuria and $48 \%$ exhibited hematuria (not peer-reviewed) (39). D-dimer was elevated in 70\% of 182 patients and high levels of D-dimer were common in severe and deceased cases (39). In another retrospective study of 333 patients, about $75 \%$ experienced urine dipstick abnormalities or AKI (40). In the first studies during the pandemic spread, incidence of AKI was reported from 3 to $9 \%$ of patients, but more recent studies reported an incidence rate of $15 \%$ $(17,41)$. In one observational study of 5,449 hospitalized patients, the incidence of AKI was 36.6 with $14.3 \%$ of patients requiring dialysis and was even higher in patients admitted to the ICU (42). Moreover, patients with AKI had higher mortality compared to those without AKI (35 and 16.3\%, respectively) (42).

AKI is more common among patients with more severe disease, particularly in those recovering in the ICU, and is considered a negative prognostic factor for survival (43). In a retrospective study of 333 patients with COVID-19 pneumonia, those who presented with kidney dysfunction had higher mortality rates than patients without kidney involvement (11.2 and $1.2 \%$, respectively) (40). 
In a single-center, retrospective, observational study of 287 patients, 55 patients presented with AKI as defined by the Kidney Disease Improving Global Outcomes (KDIGO). These patients were significantly older, more likely male, and with other comorbidities, including chronic renal insufficiency, hypertension, and cerebrovascular disease, and tended to have more severe pneumonia (not peer-reviewed) (41). Of these patients, $14.3 \%$ presented with AKI at stage 1, while $4.9 \%$ of patients presented with stage 2 or 3 (41). A comparison of outcomes according to AKI status and stage found that comparing non-AKI patients to those who developed AKI, the last had higher mortality rates, especially when AKI was severe (mortality: 3.0, 7.3, and 64.3\% for non-AKI, AKI stage 1, and AKI stages $2 / 3$, respectively) (41).

In another study of 701 patients, $11.9 \%$ of those with elevated baseline creatinine developed AKI compared to $4.0 \%$ in patients with normal baseline creatinine (5). In-hospital mortality was significantly higher in patients with proteinuria, hematuria, elevated baseline creatinine and urea, and AKI stage 2-3 (5).

High dose diuretics and K-binding resins have been used to delay the need of dialysis (44-46). Careful fluid management to reduce the risk of pulmonary edema in patients with severe ARDS from COVID-19 is the first goal, so in the absence of hypotension and shock, a negative fluid balance of $0.5-1.0 \mathrm{~L}$ per day is recommended (47).

The current management of COVID-19 associated AKI includes supportive treatment, avoiding nephrotoxic drugs, and early start, when possible, of renal replacement therapy (5). SARS, MERS, and sepsis have been successfully treated in the past with continuous renal replacement therapy (CRRT). In these cases, CRRT by hemofiltration and hemodiafiltration can contribute to the improvement of organ failure. Therefore, CRRT may be beneficial in patients with COVID-19 and sepsis syndrome, but it needs to be evaluated more carefully (48). Filters with membranes made of acrylonitrile and sodium methallyl sulfonate plus polyethyleneimine or polymethylmethacrylate could adsorb cytokines, but they should be replaced every $24 \mathrm{~h}$ (49). Finally, the new sorbent cartridges designed to remove circulating cytokines and mediators, associated with hemoadsorption and hemoperfusion, could also be considered in COVID-19 patients (50).

Prone positioning, already known to reduce mortality in other causes of severe ARDS, should be applied early. Although there is no available data on patients with COVID-19 (33), SARS-CoV2 tends to affect the peripheral and dorsal areas of the lungs. Prone positioning could potentially improve the response to a positive oxygenation (33). This, however, complicates placement of a central venous catheter and could hinder the ability to do CRRT for increased hemodynamic instability.

Due to the hypercoagulability state associated with COVID19, systemic anticoagulation with unfractionated heparin or regional citrate anticoagulation is advised (46). Since these patients experience higher filter clotting, it might be useful to choose predilution replacement fluid administration for hemofiltration, and consider using a heparin bolus together with pre-filter heparin at higher rate than usual -monitoring PTT before and during hemodialysis to avoid bleeding- in order to maintain higher blood flows (46). It is also important to consider that most COVID-19-infected patients requiring intensive care management show altered liver function which associates with an increased risk for citrate accumulation (51).

In a single-center retrospective observational study of 287 patients, Xiao et al. (41) found that most patients recover from AKI stage 1. However, patients who progress to AKI stage 2 or 3 have a very high mortality rate (41). The impact of COVID-19 on patients' long-term kidney function should be investigated further.

\section{The Mechanisms of SARS-CoV-2 Associated Kidney Injury}

The exact mechanism of kidney involvement is unclear and likely multifactorial. Kidney disease may be caused by SARS-CoV-2 binding to the ACE2 receptor on kidney cells that allows the virus to enter $(13,52,53)$. Moreover, normal kidney and intestinal tract have higher ACE2 expression than lung tissue (54). Detection of coronavirus in the kidneys and urine of patients with SARS$\mathrm{CoV}$ and SARS-CoV-2 supports the theory that the virus can directly damage the kidneys (5). However, in another study, no urine tested positive for viral RNA in 72 samples (55). Preliminary evidence in postmortem examinations of kidney tissue from six patients found severe acute tubular necrosis and lymphocyte infiltration. Additionally, SARS-CoV-2 nucleocapsid protein (NP) has been detected through immunohistochemistry in kidney tubules (56). Moreover, in one autopsy of a kidney transplant patient who died of COVID-19, viral inclusion structures were found in the endothelial cells of the kidney (57). Viral infection could induce tubular damage through the deposition of the MAC complex (the final step of the complement cascade) on tubules and infiltration of $\mathrm{CD}^{\circ} 8^{+}$macrophages in the tubule-interstitium (56). Diffuse damage in proximal tubules with the loss of brush border, vacuolar degeneration, and even necrosis were observed in a study of 26 autopsies of patients with COVID-19 (58). In the peritubular and glomerular capillary of these autopsies, diffuse erythrocyte aggregation with endothelial damage, and obstruction without fibrin thrombi or distinct fragmentation of erythrocytes or platelets were observed (58). Clusters of SARS-CoV-2 was found with electron microscopy in the tubular epithelium and podocytes (58). However, this finding could be non-specific as the presence of viral proteins may not represent direct damage mediated by the virus and instead indicate clathrin-coated vesicles $(59,60)$. Puelles et al. (61) showed the presence of SARS-CoV-2 RNA and proteins in all kidney areas, especially in glomerular cells in autopsies of three of six COVID-19 patients.

Kidney biopsies in two Afro-American patients with highrisk APOL1 genotype and COVID-19 infection showed a collapsing focal segmental glomerulosclerosis $(62,63)$. However, SARS-CoV-2 RNA was not detected in the kidney tissue raining the intriguing hypothesis that cytokine storm increased APOL1 expression leading to podocyte injury $(62,63)$. Other indirect mechanisms that potentially lead to tubular injury are sepsis, cytokine storm syndrome, shock/hemodynamic instability, rhabdomyolysis, and hypoxia of kidney tissue $(5,48)$. 
Kidney biopsies would be helpful to better understand the histologic pattern of injury (tubular, glomerular, and vascular) and the pathogenesis that could led to AKI. Unfortunately, this is very difficult to obtain given the respiratory and hemodynamic instability of AKI patients and the use of anticoagulation which increases the risk of bleeding. In addition, non-essential procedures in infected patients are not being done in most hospitals given significant risk of exposure to personnel.

\section{COVID-19 in CKD Patients}

Patients with chronic kidney disease (CKD) are known to have a higher risk of upper respiratory tract infection and pneumonia due to their persistent proinflammatory state with functional defects in innate and adaptive immunity (5). No study so far has found that chronic kidney disease is statistically correlated with severe COVID-19. However, a significant association of CKD with severe COVID-19 was observed when data of different studies were combined (64).

\section{COVID-19 in Kidney Transplant Recipients}

Chronic immunosuppression is a well-known risk factor for viral and bacterial infections, but it is also crucial to prevent graft rejection and to contrast the uncontrolled antiviral inflammatory response. Therefore, the transplant community is puzzled in trying to understand the best therapeutic approach, in the absence of any strong clinical data (8).

So far, initial presentation in transplant recipients has been reported heterogeneous to other hosts and many patients did not report contact with infected individuals. Common symptoms at disease onset have been fever, cough, asthenia, myalgias, and diarrhea (65). In a study of 36 transplant recipients, however, fever was less common than in general COVID-19 patients (66). In multiple series, transplant patients show numerous radiopacity and patchy shadows on chest radiographs often at presentation (67-71). However, in one case series of 15 kidney transplant patients, $33 \%$ had no acute radiographic findings (72). Laboratory exams often showed lymphopenia with lower CD3, CD4, and CD8 T cells especially in those patients who had received antithymocyte globulin in the weeks before the infection (66).

Until more data is available, the rules to prevent viral infection in the general population apply to transplant patients (hand hygiene, sanitization, social distancing, and avoiding areas where infected patients could be present) (73). Transplant patients with potential COVID-19 infection should not access the transplant center due to risk of viral spread.

According to the European Renal Association-European Dialysis and Transplant Association (ERA-EDTA) guidelines (74), in patients with COVID-19 and without pneumonia, complete withdrawal of immunosuppressants -particularly calcineurin inhibitors (CNI)- is discouraged. Reduction of the dosage of CNI, and withdrawal of mycophenolate, azathioprine, or mTOR-inhibitors should be individualized considering the severity of the disease (74). The concurrent use of antivirals and anti-inflammatories should be carefully considered with attention to drug-drug interactions that may affect the half-life of immunosuppressant drugs (74).
In critically ill patients, withdrawal of immunosuppression could be done while converting those patients to hydrocortisone/solumedrol. This approach may improve viral clearance but could lead to immune reconstitution and kidney's rejection $(69,75)$. It should be considered that reducing immunosuppression may exacerbate inflammation, so this approach should be cautioned in the absence of anti-inflammatory agents (see below).

In some patients, tacrolimus reduction may be preferred over complete withdrawal $(67,69)$ because of direct alleged CNI antiviral properties or CNI anti-inflammatory action (76, 77). Pending the results of clinical studies, CNI withdrawal vs. reduction may be established on a case-by-case basis depending on the severity of pneumonia.

\section{Living Kidney Donation During the COVID-19 Pandemic}

In countries with widespread community transmission, livingdonor kidney programs have been temporarily suspended. In countries where community transmission is lower, living donations should not be performed if the donor or recipient have lived in a place with high incidence or have been in contact with confirmed or suspected COVID-19 patient within 14 days.

Transplantation can be considered in highly selected cases when required as a life-saving procedure.

\section{Donation From Deceased Donors During the COVID-19 Pandemic}

In countries with sporadic COVID-19 infection, deceased donor transplants should continue. However, donors at risk of infection should not be accepted since RNAemia was reported in at least $15 \%$ in one case series, and, transmission from the donor is possible (16).

Suspension of all transplants that require T or B cell depletion (i.e., hyperimmune patients with greater title of donor-specific HLA antibodies) should be considered even in countries where the incidence of COVID-19 positive individuals is low.

In countries with widespread infection, temporary suspension of the deceased donor program for non-life-saving organs should be considered in order to prevent infection of the recipient during the post-transplant period. Even then, each kidney transplant should be considered case-by-case.

\section{COVID-19 Infection in Chronic Dialysis Patients}

Although it is known that diabetic nephropathy is an important comorbidity and AKI is one of the main risk factors for poor outcome during COVID-19 infection, the impact of the infection on other kidney diseases, like end-stage renal disease, is still unclear (8).

Wang et al. (78) described the outbreak of COVID-19 in the hemodialysis (HD) center of Renmin Hospital, Wuhan University. They identified COVID-19 in 37 individuals among $230 \mathrm{HD}$ patients (16.09\%) and 4 individuals among 33 staff (12.12\%). They presented mostly mild symptoms, and no one required admission to the ICU. During the observation, $7 \mathrm{HD}$ patients died -6 with COVID-19 and 1 without- but deaths 
were not directly related to pneumonia. The causes of death, in fact, were heart failure, hyperkalemia, and cerebrovascular disease (not peer-reviewed) (79). In a report of five HD patients, diarrhea was the most common symptom, whereas fever, cough, and dyspnea were not present, thus making the diagnose harder (80). In one retrospective multicenter study of 7,154 hemodialyzed patients, about $2 \%$ were confirmed having COVID-19 infection and only about $50 \%$ of them presented fever while about $20 \%$ of patients were asymptomatic (81). The mortality rate among these patients is greater than the general population with COVID-19 peaking at about 31\% (81). The same mortality rate was reported in another retrospective study of 59 dialyzed patients ( 2 on peritoneal dialysis and 57 on hemodialysis) (82).

Circulating CD4 and CD8T cells, NK cells, and proinflammatory cytokines are significantly lower in COVID-19 HD patients, compared to non-HD COVID-19 individuals (79). Consistently, HD patients infected by SARS-CoV-2 are more likely to present mild symptoms with lower risk of developing ARDS compared to COVID-19 patients not on HD (79). However, the reduced inflammatory response in HD patients suggests that they may be at higher risk of being infected with SARS-CoV-2. Therefore, additional prevention measures are essential in managing the epidemic in HD centers (8). The impaired immune response in $\mathrm{HD}$ patients correlates to longer time to clear the virus requiring longer time in isolation corresponding with the outbreak of SARS in $2003(79,83)$.

An interim guidance for outpatient HD facilities has been recently released by the Centers for Disease Control and Prevention (CDC) (84). Early recognition and isolation of individuals with respiratory infection, isolation of infected patients from other hemodialyzed patients, and the use of personal protective equipment are high priority (85). During routine clinical visits, face masks, and eye shields are sufficient, while during high-risk procedures, N95 respirators and other respiratory protection devices are required. Chinese Society of Nephrology and the Taiwan Society of Nephrology have recently published detailed guidelines for managing COVID-19 outbreaks in dialysis units $(8,48)$.

Patients on peritoneal dialysis should be managed from home, using telemedicine assistance or other systems for communication whenever possible (86).

\section{COVID-19 TREATMENT}

Currently, no specific treatment against SARS-CoV-2 has been developed, but research thus far has revealed several agents that may have potential efficacy against COVID-19 (Table 1). Several broad-spectrum antiviral drugs, already approved for other viral infections, are now being tested to treat COVID-19. Meanwhile, anti-inflammatory drugs are given to prevent ARDS. The use of antiviral therapy should be applied early during the disease, when anti-inflammatory therapy, like corticosteroids, could be harmful and induce viral replication. However, once the disease is advanced and the hyper inflammation is the driver of the disease, the use of anti-inflammatories is suggested, while antiviral therapy could be ineffective (107).

\section{Antivirals}

\section{Lopinavir/Ritonavir}

Lopinavir/Ritonavir is a protease inhibitor approved for the treatment of HIV (108). Lopinavir was approved for the treatment of SARS-CoV during the epidemic of 2003 because it showed inhibitory activity against the virus in vitro. Lopinavir was also used against MERS-CoV because it has inhibitory activity against the virus both in vitro and in an animal models (109, 110). Lopinavir is used in combination with ritonavir because it increases the plasma half-life of lopinavir inhibiting the cytochrome P450 (111).

Despite these promising results, a Chinese clinical trial (ChiCTR2000029308) in patients with SARS-CoV-2 infection showed that treatment with lopinavir-ritonavir added to standard supportive care was not associated with a statistically significant difference over standard care alone in the time to clinical improvement or mortality (87).

\section{Hydroxychloroquine}

SARS-CoV-2 needs an acidic endosomal $\mathrm{pH}$ for processing and internalization (8). In vitro data indicate that the antimalarial drug chloroquine exerts antiviral effects by increasing endosomal $\mathrm{pH}$ and abrogating virus-endosome fusion. Antiviral effects in vivo of hydroxychloroquine may be enhanced by the immunemodulating activity that this drug offers (112). Preliminary data suggests potential efficacy of hydroxychloroquine, particularly combined with azithromycin, in viral clearance. Hydroxychloroquine is often administered in conjunction with azithromycin, but caution is needed since these drugs are both associated with QT prolongation that could cause arrhythmias especially when combined with medications used to treat other chronic conditions (e.g., kidney failure, hepatic disease). In a small randomized study of 62 COVID-19 positive patients (not peer-reviewed) patients treated with hydroxychloroquine treatment showed an improvement in the clinical recovery and in the resolution of pneumonia compared to the control group (113). However, one observational study of 1,376 patients with COVID-19 treated with hydroxychloroquine showed no difference in the risk of being intubated or death compared to patients who did not receive hydroxychloroquine (88). The quick evolution of the COVID-19 pandemic and its associated mortality resulted in hasty publications occasionally not based on reliable data, which subsequently led to their retraction (114). Even when there is such sense of urgency, scrutiny and special attention to primary data would be prudent.

\section{Favipiravir}

Favipiravir is a drug approved for treatment of severe influenza virus infection in China. It is a new type of RNA-dependent RNA polymerase (RdRp) inhibitor. It inhibits viral polymerase activity because it can enter the cell and be recognized as a substrate by RNA polymerase when it is phosphoribosylated. It is capable of blocking the replication of several RNA virus (108). One randomized, controlled, open-label multicenter trial, showed no significant difference in disease recovery between 116 COVID19 patients treated with favipiravir compared to 120 patients treated with arbidol, but the time of symptom improvement 
TABLE 1 | Main treatments, currently in use, and under investigation, in COVID-19 patients.

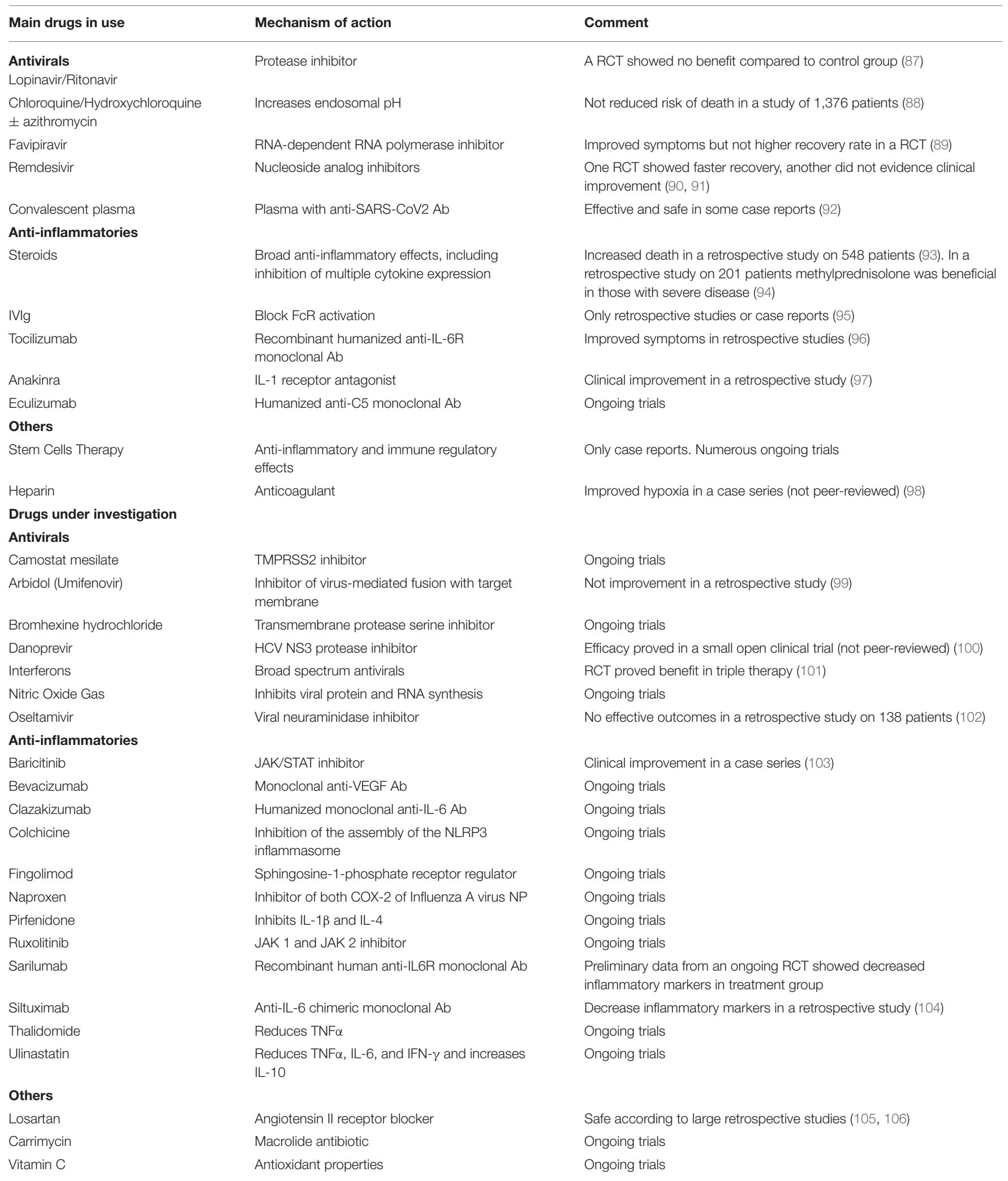

Ab: antibody; COX-2: cyclooxygenase-2; HCV: hepatitis C virus; IL-6R: interleukin-6 (LL-6) receptor; NLRP3: NLR Family Pyrin Domain Containing 3; RCT: randomized controlled trial; TMPRSS2: transmembrane serine protease 2; TNF : tumor necrosis factor $\alpha$; VEGF: vascular endothelial growth factor. 
was shorter in favipiravir-treated individuals (not peer-reviewed) (89). Favipiravir is currently being tested in several clinic trials on COVID-19 patients.

\section{Remdesivir}

Remdesivir has broad-spectrum antiviral activity because it is an adenosine analog that can determine pre-mature termination of viral RNA $(108,112)$. It is currently being tested for treatment of Ebola virus infection and, in the future, might be useful to treat several other RNA virus infections $(112,115)$. Wang et al. (112) showed that viral infections in a human cell line, which is sensitive to SARS-CoV-2, could be inhibited by remdesivir.

In a cohort of 53 severely ill COVID-19 patients treated with remdesivir and observed for 18 days, $68 \%$ of patients improved in oxygen-support status, with a mortality of $13 \%$ overall (116). In a preliminary report of a randomized trial of 1,059 patients with COVID-19, those who received remdesivir had a faster recovery than patients who received a placebo (90). Goldman et al. (117) found that in 397 severe COVID-19 pneumonia patients without mechanical ventilation at baseline, there was no significant difference if they were treated for 5 or 10 days. However, in a randomized clinical trial of 158 patients, remdesivir was not associated with a significant clinical improvement compared to the placebo group comprised of 78 patients (91). Numerous clinical trials are ongoing to test remdesivir and its safety against COVID-19 infection.

\section{Convalescent Plasma}

The use of convalescent plasma was recommended as an empirical treatment during outbreaks of Ebola virus in 2014 and as a protocol for treatment of MERS (118).

Shen et al. (118) administered convalescent plasma transfusions to 5 patients with COVID-19 and ARDS. The donors had recovered from SARS-CoV-2 and had been asymptomatic for at least 10 days with documented anti-SARSCoV-2 antibodies. In all patients, the neutralizing antibody titers significantly increased after plasma transfusion, the viral load declined, and the clinical conditions improved (118). One study of 10 patients infected by SARS-CoV-2 demonstrated the safety and efficacy of convalescent plasma transfusion, with improvement of clinical symptoms, reduction of pulmonary lesions, increase of lymphocytes count and titer of neutralizing antibodies, disappearance of SARS-CoV-2 RNA, and a better clinical outcome compared to 10 matched control patients (92).

Several other ongoing trials are testing the safety/efficacy profile of convalescent plasma transfusion in patients with SARS-CoV-2.

\section{Camostat Mesylate}

Camostat mesylate is a TMPRSS2 inhibitor. TMPRSS2 is a cellular protease that, together with ACE2, allows SARS-CoV-2 to enter target cells (13). Camostat mesylate, already approved for some forms of cancer and hepatitis, is being tested in ongoing clinical trial against COVID-19.

\section{Anti-inflammatory Agents}

Early reports, mainly from China, suggested that over $60 \%$ of severely ill COVID-19 patients presented with additional organ dysfunction syndromes (119). This has been, at least in part, related to a sepsis-like syndrome induced by high levels of circulating cytokines. Cytokine storm may be induced by a superimposed septic syndrome or by the direct effect of the virus on the infected host (119). It has been suggested that anti-inflammatory drugs may ameliorate COVID-19 infections.

\section{Steroids}

The World Health Organization does not recommend the use of steroids because they could inhibit viral clearance and prolongate viremia (48). Stockman et al. (120) analyzed treatments used during the SARS outbreak of 2002-2003. They found that in 29 studies, use of steroids in 25 cases did not detect any efficacy and in 4 cases steroids could be harmful presenting side effects like delayed viral clearance, avascular necrosis, diabetes, and psychosis $(33,120)$. Therefore, systemic use of glucocorticoids need to be cautiously pursued (31). In a study of 548 patients with severe disease treated with high-dose corticosteroids, patients had an increased death rate than those not treated with corticosteroids (93). Some trials are exploring the effectiveness and safety of glucocorticoids in the treatment of COVID-19.

\section{JAK-STAT Inhibitors}

JAK-STAT inhibitors, like baricitinib, fedratinib, and ruxolitinib are potent anti-inflammatory drugs that are approved for rheumatoid arthritis and myelofibrosis. Patients infected with SARS-CoV-2 often present increased levels of pro-inflammatory cytokines and may benefit from the use of these drugs. A case series reported clinical improvement in COVID-19 patients treated with baricitinib (103). These drugs are currently being tested in multiple randomized controlled trials.

\section{Intravenous Immunoglobulin}

Intravenous immunoglobulin (IVIg) may reduce SARS-CoV-2induced inflammatory response by blocking FcR activation on monocytes. There are several clinical trials that will evaluate the efficacy and safety of IVIg therapy in patients with pneumonia caused by SARS-CoV-2. In a retrospective study of 58 COVID19 patients, the use of IVIg within $48 \mathrm{~h}$ of admission increased in-hospital recovery and reduced 28-day mortality rate (95).

\section{Stem Cell Therapy}

Mesenchymal stem cells (MSC) have immunomodulatory properties because they can inhibit $\mathrm{T}$ cell and macrophage activation and induce the formation of regulatory $\mathrm{T}$ cell and antiinflammatory macrophages $(121,122)$. Their anti-inflammatory activity inhibits the secretion of IL-1, TNF $\alpha$, IL-6, IL-12, and IFN$\gamma$ and promotes IL-10 and VEGF secretion which prevents lung tissue damage $(121,123)$. There is a pre-proof clinical trial that demonstrated the efficacy of the MSC treatment in patients with ARDS secondary to Influenza A (H7N9) infection (124). Several ongoing clinical trials are testing the mesenchymal stem cells therapy against SARS-CoV-2.

\section{IL-6-Inhibitors}

Tocilizumab, a drug used to treat rheumatoid arthritis, is a monoclonal antibody against the IL-6 receptor. Since elevated IL-6 levels are commonly found in COVID-19, tocilizumab is now under evaluation by a multicenter randomized controlled trial (ChiCTR2000029765). The preliminary clinical results are 
encouraging (48). In an uncontrolled study of 21 patients treated affected with severe COVID-19 infection, the use of tocilizumab improved symptoms and radiological findings (96). Numerous other studies are ongoing to test this drug in patients affected by COVID-19.

Other IL-6 inhibitors are being tested to treat COVID-19, including sarilumab and siltuximab. The latter showed a decrease in inflammatory markers in a study of 21 COVID-19 patients (not peer-reviewed) (104).

\section{Ulinastatin}

Ulinastatin is a serin protease inhibitor with anti-inflammatory effects approved in China and Japan for the treatment of acute pancreatitis and sepsis (123). There is an ongoing clinical trial (NCT04393311) that is testing the safety and efficacy of ulinastatin compared to placebo in COVID-19 patients.

\section{Anakinra}

Anakinra has been approved by the FDA for the treatment of rheumatoid arthritis and neonatal-onset multisystem inflammatory disease. It is a recombinant human interleukin-1 receptor antagonist (IL-1Ra), and it is currently being tested in ongoing trials with COVID-19 patients to contrast the uncontrolled inflammatory response. In one retrospective study of 29 patients with COVID-19, those that received high-dose of Anakinra in combination with standard treatment had a faster respiratory improvement compared to 16 patients who received standard therapy alone (72 and 50\%, respectively) (97).

\section{RAS Inhibitors and Their Role in the Kidney?}

The receptor for SARS-CoV-2, angiotensin-converting enzyme 2 (ACE2), is a membrane-bound aminopeptidase whose function is to cleave angiotensin I and angiotensin II into two peptides, angiotensin-(1-9), and angiotensin-(1-7) (8). Angiotensin-(19) has cardiovascular-protective effects and angiotensin-(1-7) acts as vasodilator and has anti-proliferative, and anti-fibrotic function $(8,125,126)$.

Experimental animal models showed that, although ACE inhibitors and ARBs do not directly affect ACE2 activity, these agents can upregulate the expression and activity of the receptor in heart and kidney tissue (127). These drugs are commonly prescribed for patients with diabetes or cardiovascular disease who have higher risk of severe COVID-19 disease which has raised concern for the use of these drugs during the infection (8). However, the increased expression of ACE2 could limit the viral spread because it is not accompanied by an increase of TMPRSS2,

\section{REFERENCES}

1. McMichael TM, Currie DW, Clark S, Pogosjans S, Kay M, Schwartz NG, et al. Epidemiology of Covid-19 in a long-term care facility in King County, Washington. N Engl J Med. (2020) 382:2005-11. doi: 10.1056/NEJMoa2005412

2. Munster VJ, Koopmans M, van Doremalen N, van Riel D, de Wit E. A novel coronavirus emerging in China - Key questions for impact assessment. $N$ Engl J Med. (2020) 382:692-4. doi: 10.1056/NEJMp2000929 so the virus could be tied to the receptor but could not enter the cells (8). Another possible protective role of ARBs in the lungs is mediated by angiotensin-(1-7) that has anti-proliferative and anti-fibrotic activity (8). Experimental animal models of acute lung injury, including a model of SARS-CoV infection, showed that ARBs reduce Ang II-mediated lung damage and therefore attenuate COVID-19 infection (127). In a retrospective study of 6,272 patients with COVID-19 and matched COVID-19 negative controls, infected patients were associated with increased use of RAAS inhibitors, but these drugs did not correlate with a more severe disease after multivariable adjustment (105). The study by Reynolds et al. (106) did not find any correlation between the use of anti-hypertensive drugs, such as RAS inhibitors (both angiotensin-receptor blockers and ACE inhibitors), calciumchannel blockers, beta-blockers or thiazide diuretics and the risk of infection or of having a severe disease in 5,894 patients.

The European and American Cardiology Societies, remarked that there is no evidence of a noxious effect of RAS inhibitors in patients affected by COVID-19 (128, 129). Moreover, discontinuation of RAS inhibitor both in healthy and infected individuals could be dangerous, especially in high-risk patients, so they suggest to maintain the ongoing therapy (130).

\section{CONCLUSIONS}

SARS-CoV-2 effects on the kidney and in patient with underlying kidney disease is not well-characterized. Preliminary data has indicated that previous kidney disease could represent a risk factor, especially in elderly patients, for a more severe disease course. SARS-CoV-2 infects the kidneys and may induce acute kidney injury. While there is no current specific therapy, many drugs both antiviral and/or anti-inflammatory are being actively tested in randomized trials. Further studies are necessary to better understand disease pathology, acute kidney injury associated with infection, long-term renal consequences, and potential therapies. Rigorously controlled interventional studies and international registry analyses will be crucial to define risk factor and the best therapeutic approaches to resolving COVID19 disease outcomes.

\section{AUTHOR CONTRIBUTIONS}

CB wrote manuscript the initial draft. MW, GZ, and LR participated in the manuscript writing. PC supervised the manuscript. All authors contributed to the article and approved the submitted version.
3. Available online at: https://www.who.int/emergencies/diseases/novelcoronavirus-2019 (accessed May 26, 2020).

4. Velavan TP, Meyer CG. The COVID-19 epidemic. Trop Med Int Health. (2020) 25:278-80. doi: 10.1111/tmi.13383

5. Cheng Y, Luo R, Wang K, Zhang M, Wang Z, Dong L, et al. Kidney disease is associated with in-hospital death of patients with COVID-19. Kidney Int. (2020) 97:829-38. doi: 10.1016/j.kint.2020.03.005

6. Zhou P, Yang XL, Wang XG, Hu B, Zhang L, Zhang W, et al. A pneumonia outbreak associated with a new coronavirus of probable 
bat origin. Nature. (2020) 579:270-3. doi: 10.1038/s41586-0202012-7

7. Verity R, Okell LC, Dorigatti I, Winskill P, Whittaker C, Imai N, et al. Estimates of the severity of coronavirus disease 2019: a model-based analysis. Lancet Infect Dis. (2020) 20:669-77. doi: 10.1016/S1473-3099(20)30243-7

8. Perico L, Benigni A, Remuzzi G. Should COVID-19 concern nephrologists? why and to what extent? the emerging impasse of angiotensin blockade. Nephron. (2020) 144:213-21. doi: 10.1159/000507305

9. Weston S, Frieman MB. COVID-19: knowns, unknowns, and questions. mSphere. (2020) 5:e00203-20. doi: 10.1128/mSphere.00203-20

10. Zhang H, Penninger JM, Li Y, Zhong N, Slutsky AS. Angiotensin-converting enzyme 2 (ACE2) as a SARS-CoV-2 receptor: molecular mechanisms and potential therapeutic target. Intensive Care Med. (2020) 46:58690. doi: 10.1007/s00134-020-05985-9

11. Available online at: https://www.proteinatlas.org/ENSG00000130234-ACE2/ tissue (accessed June 29, 2020).

12. Li W, Moore MJ, Vasilieva N, Sui J, Wong SK, Berne MA, et al. Angiotensinconverting enzyme 2 is a functional receptor for the SARS coronavirus. Nature. (2003) 426:450-4. doi: 10.1038/nature02145

13. Hoffmann M, Kleine-Weber H, Schroeder S, Krüger N, Herrler T, Erichsen $S$, et al. SARS-CoV-2 cell entry depends on ACE2 and TMPRSS2 and is blocked by a clinically proven protease inhibitor. Cell. (2020) 181:27180.e8. doi: 10.1016/j.cell.2020.02.052

14. Li X, Geng $\mathrm{M}$, Peng $\mathrm{Y}$, Meng L, Lu S. Molecular immune pathogenesis and diagnosis of COVID-19. J Pharm Anal. (2020) 10:102-8. doi: 10.1016/j.jpha.2020.03.001

15. Shi Y, Wang Y, Shao C, Huang J, Gan J, Huang X, et al. COVID-19 infection: the perspectives on immune responses. Cell Death Differ. (2020) 27:1451-4. doi: 10.1038/s41418-020-0530-3

16. Huang C, Wang Y, Li X, Ren L, Zhao J, Hu Y, et al. Clinical features of patients infected with 2019 novel coronavirus in Wuhan, China. Lancet. (2020) 395:497-506. doi: 10.1016/S0140-6736(20)30183-5

17. Wan S, Yi Q, Fan S, Lv J, Zhang X, Guo L, et al. Relationships among lymphocyte subsets, cytokines, and the pulmonary inflammation index in coronavirus (COVID-19) infected patients. Br J Haematol. (2020) 189:42837. doi: $10.1111 /$ bjh. 16659

18. Diao B, Wang C, Tan Y, Chen X, Liu Y, Ning L, et al. Reduction and functional exhaustion of $\mathrm{T}$ cells in patients with coronavirus disease 2019 (COVID-19). Front Immunol. (2020) 11:827. doi: 10.3389/fimmu.202 0.00827

19. Cravedi P, Heeger PS. Complement as a multifaceted modulator of kidney transplant injury. J Clin Invest. (2014) 124:2348-54. doi: 10.1172/JCI72273

20. Gao $\mathrm{T}, \mathrm{Hu} \mathrm{M}$, Zhang $\mathrm{X}, \mathrm{Li} \mathrm{H}$, Zhu L, Liu $\mathrm{H}$, et al. Highly pathogenic coronavirus $\mathrm{N}$ protein aggravates lung injury by MASP-2-mediated complement over-activation. medRxiv. (2020). doi: 10.1101/2020.03.29.20041962. [Epub ahead of print].

21. Magro C, Mulvey JJ, Berlin D, Nuovo G, Salvatore S, Harp J, et al. Complement associated microvascular injury and thrombosis in the pathogenesis of severe COVID-19 infection: a report of five cases. Transl Res. (2020) 220:1-13. doi: 10.1016/j.trsl.2020.04.007

22. Smeeth L, Thomas SL, Hall AJ, Hubbard R, Farrington P, Vallance P. Risk of myocardial infarction and stroke after acute infection or vaccination. $N$ Engl J Med. (2004) 351:2611-8. doi: 10.1056/NEJMoa041747

23. Corrales-Medina VF, Musher DM, Wells GA, Chirinos JA, Chen L, Fine MJ. Cardiac complications in patients with community-acquired pneumonia: incidence, timing, risk factors, and association with short-term mortality. Circulation. (2012) 125:773-81. doi: 10.1161/CIRCULATIONAHA.111.040766

24. Davidson JA, Warren-Gash C. Cardiovascular complications of acute respiratory infections: current research and future directions. Expert Rev Anti Infect Ther. (2019) 17:939-42. doi: 10.1080/14787210.2019.1689817

25. Zhou F, Yu T, Du R, Fan G, Liu Y, Liu Z, et al. Clinical course and risk factors for mortality of adult inpatients with COVID-19 in Wuhan, China: a retrospective cohort study. The Lancet. (2020) 395:105462. doi: 10.1016/S0140-6736(20)30566-3

26. Agarwal PP, Cinti S, Kazerooni EA. Chest radiographic and CT findings in novel swine-origin influenza A (H1N1) virus (S-OIV) infection. AJR Am J Roentgenol. (2009) 193:1488-93. doi: 10.2214/AJR.09.3599
27. Tang N, Bai H, Chen X, Gong J, Li D, Sun Z. Anticoagulant treatment is associated with decreased mortality in severe coronavirus disease 2019 patients with coagulopathy. J Thromb Haemost. (2020) 18:10949. doi: $10.1111 /$ jth.14817

28. Zhang Y, Xiao M, Zhang S, Xia P, Cao W, Jiang W, et al. Coagulopathy and Antiphospholipid Antibodies in Patients with Covid-19. N Engl J Med. (2020) 382:e38. doi: 10.1056/NEJMc2007575

29. Gates B. Responding to Covid-19 - A once-in-a-century pandemic? N Engl J Med. (2020) 382:1677-9. doi: 10.1056/NEJMp2003762

30. Hoehl S, Rabenau H, Berger A, Kortenbusch M, Cinatl J, Bojkova D, et al. Evidence of SARS-CoV-2 infection in returning travelers from Wuhan, China. N Engl J Med. (2020) 382:1278-80. doi: 10.1056/NEJMc20 01899

31. Jin YH, Cai L, Cheng ZS, Cheng H, Deng T, Fan YP, et al. A rapid advice guideline for the diagnosis and treatment of 2019 novel coronavirus (2019-nCoV) infected pneumonia (standard version). Mil Med Res. (2020) 7:4. doi: 10.1186/s40779-020-0233-6

32. van Doremalen N, Bushmaker T, Morris DH, Holbrook MG, Gamble A, Williamson BN, et al. Aerosol and surface stability of SARS-CoV2 as compared with SARS-CoV-1. N Engl J Med. (2020) 382:15647. doi: $10.1056 / \mathrm{NEJMc} 2004973$

33. Phua J, Weng L, Ling L, Egi M, Lim CM, Divatia JV, et al. Intensive care management of coronavirus disease 2019 (COVID19): challenges and recommendations. Lancet Respir Med. (2020) 8:506-17. doi: 10.1016/S2213-2600(20)30161-2

34. Gautret P, Lagier JC, Parola P, Hoang VT, Meddeb L, Mailhe M, et al. Hydroxychloroquine and azithromycin as a treatment of COVID-19: results of an open-label non-randomized clinical trial. Int J Antimicrob Agents. (2020) 105949. doi: 10.1016/j.ijantimicag.2020.105949. [Epub ahead of print].

35. Guan W, Ni Z, Hu Y, Liang W, Ou C, He J, et al. Clinical characteristics of coronavirus disease 2019 in China. N Engl J Med. (2020) 382:170820. doi: 10.1056/NEJMoa2002032

36. Yang X, Yu Y, Xu J, Shu H, Xia J, Liu H, et al. Clinical course and outcomes of critically ill patients with SARS-CoV-2 pneumonia in Wuhan, China: a single-centered, retrospective, observational study. Lancet Respir Med. (2020) 8:475-81. doi: 10.1016/S2213-2600(20)30079-5

37. Deng Y, Liu W, Liu K, Fang YY, Shang J, Zhou L, et al. Clinical characteristics of fatal and recovered cases of coronavirus disease 2019 in Wuhan, China: a retrospective study. Chin Med J. (2020) 133:12617. doi: $10.1097 / \mathrm{CM} 9.0000000000000824$

38. Wang L, Li X, Chen H, Yan S, Li D, Li Y, et al. Coronavirus disease 19 infection does not result in acute kidney injury: an analysis of 116 hospitalized patients from Wuhan, China. Am J Nephrol. (2020) 51:3438. doi: $10.1159 / 000507471$

39. Li Z, Wu M, Yao J, Guo J, Liao X, Song S, et al. Caution on kidney dysfunctions of COVID-19 patients. medRxiv. (2020). doi: 10.1101/2020.02.08.20021212. [Epub ahead of print].

40. Pei G, Zhang Z, Peng J, Liu L, Zhang C, Yu C, et al. Renal involvement and early prognosis in patients with COVID-19 pneumonia. J Am Soc Nephrol. (2020) 31:1157-65. doi: 10.1681/ASN.2020030276

41. Xiao G, Hu H, Wu F, Sha T, Huang Q, Li H, et al. Acute kidney injury in patients hospitalized with COVID-19 in Wuhan, China: a single-center retrospective observational study. medRxiv. (2020). doi: 10.1101/2020.04.06.20055194. [Epub ahead of print].

42. Hirsch JS, Ng JH, Ross DW, Sharma P, Shah HH, Barnett RL, et al. Acute kidney injury in patients hospitalized with COVID-19. Kidney Int. (2020) 98:209-18. doi: 10.1016/j.kint.2020.05.006

43. Durvasula R, Wellington T, McNamara E, Watnick S. COVID-19 and kidney failure in the acute care setting: our experience from seattle. Am J Kidney Dis. (2020) 76:4-6. doi: 10.1053/j.ajkd.2020.04.001

44. Edrees F, Li T, Vijayan A. Prolonged intermittent renal replacement therapy. Adv Chronic Kidney Dis. (2016) 23:195-202. doi: 10.1053/j.ackd.2016.03.003

45. Cullis B, Abdelraheem M, Abrahams G, Balbi A, Cruz DN, Frishberg Y, et al. Peritoneal dialysis for acute kidney injury. Perit Dial Int J Int Soc Perit Dial. (2014) 34:494-517. doi: 10.3747/pdi.2013.00222

46. Available online at: http://www.nephjc.com/news/covidaki (accessed April 09, 2020). 
47. Matthay MA, Aldrich JM, Gotts JE. Treatment for severe acute respiratory distress syndrome from COVID-19. Lancet Respir Med. (2020) 8:4334. doi: 10.1016/S2213-2600(20)30127-2

48. Naicker S, Yang CW, Hwang SJ, Liu BC, Chen JH, Jha V. The novel coronavirus 2019 epidemic and kidneys. Kidney Int. (2020) 97:8248. doi: 10.1016/j.kint.2020.03.001

49. Ronco C, Reis T. Kidney involvement in COVID-19 and rationale for extracorporeal therapies. Nat Rev Nephrol. (2020) 16:308-10. doi: 10.1038/s41581-020-0284-7

50. Ronco C, Navalesi P, Vincent JL. Coronavirus epidemic: preparing for extracorporeal organ support in intensive care. Lancet Respir Med. (2020) 8:240-1. doi: 10.1016/S2213-2600(20)30060-6

51. Alberici F, Delbarba E, Manenti C, Econimo L, Valerio F, Pola A, et al. Management of patients on dialysis and with kidney transplantation during the SARS-CoV-2 (COVID-19) pandemic in Brescia, Italy. Kidney Int Rep. (2020) 5:580-5. doi: 10.1016/j.ekir.2020.04.001

52. Lan J, Ge J, Yu J, Shan S, Zhou H, Fan S, et al. Structure of the SARS-CoV-2 spike receptor-binding domain bound to the ACE2 receptor. Nature. (2020) 581:215-20. doi: 10.1038/s41586-020-2180-5

53. Letko M, Marzi A, Munster V. Functional assessment of cell entry and receptor usage for SARS-CoV-2 and other lineage B betacoronaviruses. Nat Microbiol. (2020) 5:562-9. doi: 10.1038/s41564-020-0688-y

54. Du M, Cai G, Chen F, Christiani DC, Zhang Z, Wang M. Multiomics evaluation of gastrointestinal and other clinical characteristics of severe acute respiratory syndrome coronavirus 2 and coronavirus disease 2019. Gastroenterology. (2020) 158:2298-301.e7. S001650852030 3991.

55. Wang W, Xu Y, Gao R, Lu R, Han K, Wu G, et al. Detection of SARSCoV-2 in different types of clinical specimens. JAMA. (2020) 323:18434. doi: 10.1001/jama.2020.3786

56. Diao B, Wang C, Wang R, Feng Z, Tan Y, Wang H, et al. Human kidney is a target for novel severe acute respiratory syndrome coronavirus 2 (SARS-CoV-2) infection. medRxiv. (2020). doi: 10.1101/2020.03.04.20 031120. [Epub ahead of print].

57. Varga Z, Flammer AJ, Steiger P, Haberecker M, Andermatt R, Zinkernagel AS, et al. Endothelial cell infection and endotheliitis in COVID-19. Lancet. (2020) 395:1417-8. doi: 10.1016/S0140-6736(20)30937-5

58. Su H, Yang M, Wan C, Yi LX, Tang F, Zhu HY, et al. Renal histopathological analysis of 26 postmortem findings of patients with COVID-19 in China. Kidney Int. (2020) 98:219-27. doi: 10.1016/j.kint.2020.04.003

59. Calomeni E, Satoskar A, Ayoub I, Brodsky S, Rovin BH, Nadasdy T. Multivesicular bodies mimicking SARS-CoV-2 in patients without COVID19. Kidney Int. (2020) 98:233-4. doi: 10.1016/j.kint.2020.05.003

60. Miller SE, Brealey JK. Visualization of putative coronavirus in kidney. Kidney Int. (2020) 98:231-2. doi: 10.1016/j.kint.2020.05.004

61. Puelles VG, Lütgehetmann M, Lindenmeyer MT, Sperhake JP, Wong MN, Allweiss L, et al. Multiorgan and renal tropism of SARS-CoV-2. N Engl J Med. (2020) NEJMc2011400. doi: 10.1056/NEJMc2011400. [Epub ahead of print].

62. Larsen CP, Bourne TD, Wilson JD, Saqqa O, Sharshir MA. Collapsing glomerulopathy in a patient with COVID-19. Kidney Int Rep. (2020) 5:9359. doi: 10.1016/j.ekir.2020.04.002

63. Kissling S, Rotman S, Gerber C, Halfon M, Lamoth F, Comte D, et al. Collapsing glomerulopathy in a COVID-19 patient. Kidney Int. (2020) 98:228-31. doi: 10.1016/j.kint.2020.04.006

64. Henry BM, Lippi G. Chronic kidney disease is associated with severe coronavirus disease 2019 (COVID-19) infection. Int Urol Nephrol. (2020) 52:1193-4. doi: 10.1007/s11255-020-02451-9

65. Pereira MR, Mohan S, Cohen DJ, Husain SA, Dube GK, Ratner LE, et al. COVID-19 in solid organ transplant recipients: initial report from the US epicenter. Am J Transplant. (2020) 20:1800-8. doi: 10.1111/ajt.15941

66. Akalin E, Azzi Y, Bartash R, Seethamraju H, Parides M, Hemmige V, et al. Covid-19 and kidney transplantation. N Engl J Med. (2020) 382:24757. doi: 10.1056/NEJMc2011117

67. Banerjee D, Popoola J, Shah S, Ster IC, Quan V, Phanish M. COVID19 infection in kidney transplant recipients. Kidney Int. (2020) 97:107682. doi: 10.1016/j.kint.2020.03.018

68. Zhu L, Xu X, Ma K, Yang J, Guan H, Chen S, et al. Successful recovery of COVID-19 pneumonia in a renal transplant recipient with long-term immunosuppression. Am J Transplant. (2020) 20:185963. doi: 10.1111/ajt.15869

69. Fishman JA, Grossi PA. Novel coronavirus-19 (COVID-19) in the immunocompromised transplant recipient: \#Flatteningthecurve. Am J Transplant. (2020) 20:1765-7. doi: 10.1111/ajt.15890

70. Guillen E, Pineiro GJ, Revuelta I, Rodriguez D, Bodro M, Moreno A, et al. Case report of COVID-19 in a kidney transplant recipient: does immunosuppression alter the clinical presentation? Am J Transplant. (2020) 20:1875-8. doi: 10.1111/ajt.15874

71. Alberici F, Delbarba E, Manenti C, Econimo L, Valerio F, Pola A, et al. A single center observational study of the clinical characteristics and shortterm outcome of 20 kidney transplant patients admitted for SARS-CoV2 pneumonia. Kidney Int. (2020) 97:1083-8. doi: 10.1016/j.kint.2020.04.002

72. The Columbia University Kidney Transplant Program. Early description of coronavirus 2019 disease in kidney transplant recipients in New York. J Am Soc Nephrol. (2020) 31:1150-6. doi: 10.1681/ASN.20200 30375

73. Aslam S, Mehra MR. COVID-19: yet another coronavirus challenge in transplantation. J Heart Lung Transplant. (2020) 39:408-9. doi: 10.1016/j.healun.2020.03.007

74. Maggiore U, Abramowicz D, Crespo M, Mariat C, Mjoen G, Peruzzi L, et al. How should I manage immunosuppression in a kidney transplant patient with COVID-19? An ERA-EDTA DESCARTES expert opinion. Nephrol Dial Transplant. (2020) 35:899-904. doi: 10.1093/ndt/gfaa130

75. Gandolfini I, Delsante M, Fiaccadori E, Zaza G, Manenti L, Degli Antoni A, et al. COVID-19 in kidney transplant recipients. Am J Transplant. (2020) 20: 1941-3. doi: 10.1111/ajt.15891

76. Mortola E, Endo Y, Ohno K, Watari T, Tsujimoto H, Hasegawa A. The use of two immunosuppressive drugs, cyclosporin a and tacrolimus, to inhibit virus replication and apoptosis in cells infected with feline immunodeficiency virus. Vet Res Commun. (1998) 22:553-63. doi: 10.1023/A:1006197804888

77. Russell B, Moss C, George G, Santaolalla A, Cope A, Papa S, et al. Associations between immune-suppressive and stimulating drugs and novel COVID-19-a systematic review of current evidence. Ecancermedicalscience. (2020) 14:1022. doi: 10.3332/ecancer.2020.1022

78. Wang H. Maintenance hemodialysis and COVID-19: saving lives with caution, care, and courage. Kidney Med. (2020) 2:365-6. doi: 10.1016/j.xkme.2020.03.003

79. Ma Y, Diao B, Lv X, Zhu J, Liang W, Liu L, et al. COVID-19 in hemodialysis (HD) patients: report from one HD center in Wuhan, China. medRxiv. (2020). doi: 10.1101/2020.02.24.20027201. [Epub ahead of print].

80. Wang R, Liao C, He H, Hu C, Wei Z, Hong Z, et al. COVID-19 in hemodialysis patients: a report of 5 cases. Am J Kidney Dis. (2020) 76:141-43. doi: 10.1053/j.ajkd.2020.03.009

81. Xiong F, Tang H, Liu L, Tu C, Tian JB, Lei CT, et al. Clinical characteristics of and medical interventions for COVID-19 in hemodialysis patients in Wuhan, China. J Am Soc Nephrol. (2020) 31:1387-97. doi: 10.1681/ASN.2020030354

82. Valeri AM, Robbins-Juarez SY, Stevens JS, Ahn W, Rao MK, Radhakrishnan J, et al. Presentation and outcomes of patients with ESKD and COVID-19. J Am Soc Nephrol. (2020) 31:1409-15. doi: 10.1681/ASN.2020040470

83. Kwan BCH. Severe acute respiratory syndrome in dialysis patients. J Am Soc Nephrol. (2004) 15:1883-8. doi: 10.1097/01.ASN.0000131522.16404.1F

84. Available online at: https://www.cdc.gov/coronavirus/2019-ncov/ healthcare-facilities/dialysis.html (accessed on April, 2 2020).

85. Kliger AS, Silberzweig J. Mitigating risk of COVID-19 in dialysis facilities. Clin J Am Soc Nephrol. (2020) 15:707-9. doi: 10.2215/CJN.03340320

86. Rombolà G, Heidempergher M, Pedrini L, Farina M, Aucella F, Messa P, et al. Practical indications for the prevention and management of SARS-CoV-2 in ambulatory dialysis patients: lessons from the first phase of the epidemics in Lombardy. J Nephrol. (2020) 33:193-6. doi: 10.1007/s40620-02000727-y

87. Cao B, Wang Y, Wen D, Liu W, Wang J, Fan G, et al. A trial of lopinavirritonavir in adults hospitalized with severe Covid-19. N Engl J Med. (2020) 382:1787-99. doi: 10.1056/NEJMoa2001282

88. Geleris J, Sun Y, Platt J, Zucker J, Baldwin M, Hripcsak G, et al. Observational study of hydroxychloroquine in hospitalized patients with Covid-19. N Engl J Med. (2020) 382:2411-8. doi: 10.1056/NEJMoa2012410 
89. Chen C, Zhang Y, Huang J, Yin $\mathrm{P}$, Cheng $\mathrm{Z}$, Wu J, et al. Favipiravir versus Arbidol for COVID-19: a randomized clinical trial. medRxiv. (2020). doi: 10.1101/2020.03.17.20037432. [Epub ahead of print].

90. Beigel JH, Tomashek KM, Dodd LE, Mehta AK, Zingman BS, Kalil AC, et al. Remdesivir for the treatment of Covid-19-Preliminary report. N Engl J Med. (2020). doi: 10.1056/NEJMoa2007764. [Epub ahead of print].

91. Wang Y, Zhang D, Du G, Du R, Zhao J, Jin Y, et al. Remdesivir in adults with severe COVID-19: a randomised, double-blind, placebo-controlled, multicentre trial. Lancet. (2020) 395:156978. doi: 10.1016/S0140-6736(20)31022-9

92. Duan K, Liu B, Li C, Zhang H, Yu T, Qu J, et al. Effectiveness of convalescent plasma therapy in severe COVID-19 patients. Proc Natl Acad Sci USA. (2020) 117:9490-6. doi: 10.1073/pnas.2004168117

93. Li X, Xu S, Yu M, Wang K, Tao Y, Zhou Y, et al. Risk factors for severity and mortality in adult COVID-19 inpatients in Wuhan. J Allergy Clin Immunol. (2020) 146: 110-8. doi: 10.1016/j.jaci.2020.04.006

94. Wu C, Chen X, Cai Y, Xia J, Zhou X, Xu S, et al. Risk factors associated with acute respiratory distress syndrome and death in patients with coronavirus disease 2019 pneumonia in Wuhan, China. JAMA Intern Med. (2020) 13:e200994. doi: 10.1001/jamainternmed.2020.0994

95. Xie Y, Cao S, Dong H, Li Q, Chen E, Zhang W, et al. Effect of regular intravenous immunoglobulin therapy on prognosis of severe pneumonia in patients with COVID-19. J Infect. (2020). doi: 10.1016/j.jinf.2020.03.044. [Epub ahead of print].

96. Xu X, Han M, Li T, Sun W, Wang D, Fu B, et al. Effective treatment of severe COVID-19 patients with tocilizumab. Proc Natl Acad Sci USA. (2020) 117:10970-5. doi: 10.1073/pnas.2005615117

97. Cavalli G, De Luca G, Campochiaro C, Della-Torre E, Ripa M, Canetti D, et al. Interleukin-1 blockade with high-dose anakinra in patients with COVID-19, acute respiratory distress syndrome, and hyperinflammation: a retrospective cohort study. Lancet Rheumatol. (2020) 2:e325-31. doi: 10.1016/S2665-9913(20)30127-2

98. Negri EM, Piloto B, Morinaga LK, Jardim CVP, Lamy SAED, Ferreira MA, et al. Heparin therapy improving hypoxia in COVID-19 patients - a case series. medRxiv. (2020). doi: 10.1101/2020.04.15.20067017. [Epub ahead of print].

99. Lian N, Xie H, Lin S, Huang J, Zhao J, Lin Q. Umifenovir treatment is not associated with improved outcomes in patients with coronavirus disease 2019: a retrospective study. Clin Microbiol Infect. (2020) 26:91721. doi: 10.1016/j.cmi.2020.04.026

100. Chen H, Zhang Z, Wang L, Huang Z, Gong F, Li X, et al. First clinical study using hcv protease inhibitor danoprevir to treat naive and experienced COVID-19 patients. medRxiv. (2020). doi: 10.1101/2020.03.22.20 034041. [Epub ahead of print].

101. Hung IFN, Lung KC, Tso EYK, Liu R, Chung TWH, Chu MY, et al. Triple combination of interferon beta-1b, lopinavir-ritonavir, and ribavirin in the treatment of patients admitted to hospital with COVID-19: an open-label, randomised, phase 2 trial. Lancet. (2020) 395:1695-704. doi: 10.1016/S0140-6736(20)31042-4

102. Wang D, Hu B, Hu C, Zhu F, Liu X, Zhang J, et al. Clinical characteristics of 138 hospitalized patients with 2019 novel coronavirus-infected pneumonia in Wuhan, China. JAMA. (2020) 323:1061-9. doi: 10.1001/jama.2020. 1585

103. Cantini F, Niccoli L, Matarrese D, Nicastri E, Stobbione P, Goletti D. Baricitinib therapy in COVID-19: a pilot study on safety and clinical impact. J Infect. (2020). doi: 10.1016/j.jinf.202 0.04.017. [Epub ahead of print].

104. Gritti G, Raimondi F, Ripamonti D, Riva I, Landi F, Alborghetti $\mathrm{L}$, et al. Use of siltuximab in patients with COVID-19 pneumonia requiring ventilatory support. medRxiv. (2020). doi: 10.1101/2020.04.01.20 048561. [Epub ahead of print].

105. Mancia G, Rea F, Ludergnani M, Apolone G, Corrao G. ReninAngiotensin-aldosterone system blockers and the risk of Covid19. $N$ Engl J Med. (2020) 382:2431-40. doi: 10.1056/NEJMoa20 06923

106. Reynolds HR, Adhikari S, Pulgarin C, Troxel AB, Iturrate E, Johnson $\mathrm{SB}$, et al. Renin-angiotensin-aldosterone system inhibitors and risk of
Covid-19. N Engl J Med. (2020) 382:2441-8. doi: 10.1056/NEJMoa20 08975

107. Siddiqi HK, Mehra MR. COVID-19 illness in native and immunosuppressed states: a clinical-therapeutic staging proposal. J Heart Lung Transplant. (2020) 39:405-7. doi: 10.1016/j.healun.2020.03.012

108. Dong L, Hu S, Gao J. Discovering drugs to treat coronavirus disease 2019 (COVID-19). Drug Discov Ther. (2020) 14:5860. doi: 10.5582/ddt.2020.01012

109. de Wilde AH, Jochmans D, Posthuma CC, Zevenhoven-Dobbe JC, van Nieuwkoop S, Bestebroer TM, et al. Screening of an FDAapproved compound library identifies four small-molecule inhibitors of middle east respiratory syndrome coronavirus replication in cell culture. Antimicrob Agents Chemother. (2014) 58:4875-84. doi: 10.1128/AAC.0 3011-14

110. Chan JFW, Yao Y, Yeung ML, Deng W, Bao L, Jia L, et al. Treatment with lopinavir/ritonavir or interferon- $\beta 1 \mathrm{~b}$ improves outcome of MERS-CoV infection in a nonhuman primate model of common marmoset. J Infect Dis. (2015) 212:1904-13. doi: 10.1093/infdis/jiv392

111. Lu H. Drug treatment options for the 2019-new coronavirus (2019-nCoV). Biosci Trends. (2020) 14:69-71. doi: 10.5582/bst.202 0.01020

112. Wang $M$, Cao $R$, Zhang L, Yang $X$, Liu J, Xu $M$, et al. Remdesivir and chloroquine effectively inhibit the recently emerged novel coronavirus (2019-nCoV) in vitro. Cell Res. (2020) 30:269-71. doi: 10.1038/s41422-020-0282-0

113. Chen Z, Hu J, Zhang Z, Jiang S, Han S, Yan D, et al. Efficacy of hydroxychloroquine in patients with COVID-19: results of a randomized clinical trial. medRxiv. (2020). doi: 10.1101/2020.03.22.200 40758. [Epub ahead of print].

114. Mehra MR, Ruschitzka F, Patel AN. Retraction-Hydroxychloroquine or chloroquine with or without a macrolide for treatment of COVID-19: a multinational registry analysis. Lancet. (2020). doi: 10.1016/S0140-6736(20)3 1180-6. [Epub ahead of print].

115. Mulangu S, Dodd LE, Davey RT, Tshiani Mbaya O, Proschan M, Mukadi D, et al. A randomized, controlled trial of ebola virus disease therapeutics. N Engl J Med. (2019) 381:2293-303. doi: 10.1056/NEJMoa19 10993

116. Grein J, Ohmagari N, Shin D, Diaz G, Asperges E, Castagna A, et al. Compassionate use of remdesivir for patients with severe Covid19. N Engl J Med. (2020) 382:2327-36. doi: 10.1056/NEJMoa200 7016

117. Goldman JD, Lye DCB, Hui DS, Marks KM, Bruno R, Montejano R, et al. Remdesivir for 5 or 10 days in patients with severe Covid-19. N Engl J Med. (2020). doi: 10.1056/NEJMoa2015301. [Epub ahead of print].

118. Shen C, Wang Z, Zhao F, Yang Y, Li J, Yuan J, et al. Treatment of 5 critically Ill patients with COVID-19 with convalescent plasma. JAMA. (2020) 323:15829. doi: 10.1001/jama.2020.4783

119. Ronco C, Reis T, De Rosa S. Coronavirus epidemic and extracorporeal therapies in intensive care: si vis pacem para bellum. Blood Purif. (2020) 49:255-8. doi: 10.1159/000507039

120. Stockman LJ, Bellamy R, Garner P. SARS: systematic review of treatment effects. PLoS Med. (2006) 3:e343. doi: 10.1371/journal.pmed.0030343

121. Uccelli A, de Rosbo NK. The immunomodulatory function of mesenchymal stem cells: mode of action and pathways: mesenchymal stem cells and immunity: an update. Ann N Y Acad Sci. (2015) 1351:11426. doi: $10.1111 /$ nyas. 12815

122. Ben-Mordechai T, Palevski D, Glucksam-Galnoy Y, Elron-Gross I, Margalit R, Leor J. Targeting macrophage subsets for infarct repair. J Cardiovasc Pharmacol Ther. (2015) 20:36-51. doi: 10.1177/10742484145 34916

123. Ye Q, Wang B, Mao J. The pathogenesis and treatment of the 'Cytokine Storm' in COVID-19. J Infect. (2020) 80:60713. doi: 10.1016/j.jinf.2020.03.037

124. Chen J, Hu C, Chen L, Tang L, Zhu Y, Xu X, et al. Clinical study of mesenchymal stem cell treatment for acute respiratory distress syndrome induced by epidemic Influenza A (H7N9) infection: a hint for COVID-19 treatment. Engineering. (2020). doi: 10.1016/j.eng.2020.02.006. [Epub ahead of print]. 
125. Delbridge LMD, Bienvenu LA, Mellor KM. Angiotensin-(1-9). J Am Coll Cardiol. (2016) 68:2667-9. doi: 10.1016/j.jacc.2016. 10.011

126. Mourad JJ, Levy BI. Interaction between RAAS inhibitors and ACE2 in the context of COVID-19. Nat Rev Cardiol. (2020) 17:313. doi: 10.1038/s41569-020-0368-x

127. South AM, Tomlinson L, Edmonston D, Hiremath S, Sparks MA. Controversies of renin-angiotensin system inhibition during the COVID-19 pandemic. Nat Rev Nephrol. (2020) 16:305-7. doi: 10.1038/s41581-020-0279-4

128. Available online at: https://www.eshonline.org/spotlights/esh-stabtementon-covid-19-2/ (accessed April 07, 2020).

129. Available online at: https://www.acc.org/latest-in-cardiology/articles/2020/ 03/17/08/59/hfsa-acc-aha-statement-addresses-concerns-re-using-raasantagonists-in-covid-19 (accessed April 07, 2020).

130. Vaduganathan M, Vardeny O, Michel T, McMurray JJV, Pfeffer MA, Solomon SD. Renin-Angiotensin-Aldosterone system inhibitors in patients with Covid-19. N Engl J Med. (2020) 382:1653-9. doi: 10.1056/NEJMsr20 05760

Conflict of Interest: The authors declare that the research was conducted in the absence of any commercial or financial relationships that could be construed as a potential conflict of interest.

The reviewer UM declared a past collaboration with one of the authors PC to the handling editor.

Copyright (ङ 2020 Benedetti, Waldman, Zaza, Riella and Cravedi. This is an openaccess article distributed under the terms of the Creative Commons Attribution License (CC BY). The use, distribution or reproduction in other forums is permitted, provided the original author(s) and the copyright owner(s) are credited and that the original publication in this journal is cited, in accordance with accepted academic practice. No use, distribution or reproduction is permitted which does not comply with these terms. 